\title{
White Noise and Unnecessary Evil: Balancing Security and Community in Synagogues
}

\author{
Maxim G. M. Samson ${ }^{1}$ (D)
}

Received: 23 September 2020 / Accepted: 5 April 2021 / Published online: 28 April 2021

(C) The Author(s), under exclusive licence to Springer Nature B.V. 2021

\begin{abstract}
Violent hate crimes at places of worship such as synagogues in recent years have engendered a distinctive dilemma for religious institutions: How can one ensure people's safety and security without compromising the warm and welcoming environment that these communities seek to create? Drawing upon five interviews with Jewish leaders, this article explores how this dilemma is being negotiated by synagogues in Chicago. After presenting three key predicaments faced by synagogues as regards security, the article argues that securitization should be understood as a form of "white noise," necessary to religious institutions' functioning and yet necessarily invisible. Indeed, although security is now an essential feature of many synagogues, it is also at constant risk of undermining their cordial ambience through providing a reminder of one's mortality, requiring that it be present, but in the background. Consequently, synagogues today are compelled to find a careful balance between hospitality and openness, with diverse and often paradoxical implications.
\end{abstract}

Keywords Security $\cdot$ Community $\cdot$ Places of worship $\cdot$ Synagogues $\cdot$ Hate crimes

\section{Introduction}

On April 13, 2014, a neo-Nazi and former Klansman fatally shot three people at the premises of the Jewish Community Center of Greater Kansas City and Village Shalom, a Jewish retirement community in Overland Park, Kansas (Stucker and Shoichet 2014). Then, on October 27, 2018, a white supremacist massacred eleven people at Tree of Life Congregation, a Conservative Jewish synagogue in Pittsburgh, Pennsylvania (Connelly and Italiano 2018). Exactly 6 months later, another gunman fatally shot one and injured three other community members of the Chabad of Poway synagogue in Poway, California (Paul and Mettler 2019). These events were

Maxim G. M. Samson

msamson6@depaul.edu

1 Department of Geography, DePaul University, 990 West Fullerton Avenue, Suite 4300, Chicago, IL 60614, USA 
all reprehensible for a number of obvious reasons, but part of their shocking nature is the dilemma they have engendered for synagogues and other Jewish community institutions: How can one be warm and welcoming on the one hand, but safe and secure on the other? Significantly, in all three cases the attackers appeared to select times when they could maximize their victims - respectively, a Sunday on which teenagers were participating in vocal auditions and theater rehearsals, Shabbat morning services including a baby-naming ceremony, and the last day of Passover, which additionally fell on Shabbat-magnifying the challenges of distinguishing between "safe" and "unsafe" individuals in busy Jewish community spaces. Increases in antisemitic incidents in the last 3 years reported by the Anti-Defamation League (ADL 2020), an expanding trend in anti-Jewish hate crimes over the past decade-which consistently represent the majority of religiously biased offenses disclosed by the Federal Bureau of Investigation (FBI 2020a) — and recent survey data indicating that $88 \%$ of American Jews perceive that antisemitism is a problem in the country and $82 \%$ believe it has increased over the last 5 years (American Jewish Committee; AJC 2020) also suggest a growing sense of Jewish vulnerability in the United States (U.S.). Further, it should be noted (see Samson 2020) that analogous atrocities have occurred at other places of worship in the U.S. in recent years, including churches (Emanuel African Methodist Episcopal Church, Charleston, South Carolina; First Baptist Church, Sutherland Springs, Texas; West Freeway Church of Christ in White Settlement, Texas) and a Sikh temple (Sikh Temple of Wisconsin, Oak Creek, Wisconsin). As can be seen, many religious institutions' ethic of welcoming the stranger can contribute to their vulnerability to an attack, with Jewish spaces appearing to be particularly at risk.

This article explores how this dilemma is playing out at synagogues in Chicago, Illinois, the third-largest city in the U.S. Inspired by the title of Don DeLillo's most highly acclaimed novel, it regards the securitization of synagogues, through which a difficult balance must be found between community and security, as "white noise." The subsequent section situates the research in previous scholarship on these two seemingly ambivalent objectives. Following a description of the methods (comprising five interviews with Jewish leaders), the results are presented in three subsections, each focusing on a predicament posed by security. The discussion then links the findings back to the concept of "white noise" in order to illustrate how synagogues attempt to harmonize community with security and the challenges therein, before the conclusion points to some areas in need of further consideration in future scholarship.

\section{Jewish Communities and (In)Security}

"Community" is one of the most broadly theorized terms in the social sciences. Although communities have often been conceptualized in line with Ferdinand Tönnies' (1988) renowned concept of Gemeinschaft, emphasizing personal social interactions and the importance of common values (Etzioni 1993; Putnam 2000) or interests (Crow and Allan 1994; Obst and White 2005), generally grounded on a specific place or organization, considerable recent scholarship has extended attention to 
communities that cut across national boundaries (Vertovec 2009; Djelic and Quack 2010) or are lived in more abstract spaces such as the Internet (Haythornthwaite and Kendall 2010; Lieber 2010). Indeed, it is important to recognize that a community represents a process as well as an endpoint and may transcend space rather than necessarily being associated with a place (Tigges 2006), stimulating attention to a broad range of dynamic social relations.

Crucially, in spite of the diversity of definitions available, an almost unanimous aspect of community is that it is regarded as a social good. As Zygmunt Bauman argues at the very start of Community: Seeking safety in an insecure world, the word "community" "feels good: whatever the word 'community' may mean, it is good 'to have a community', 'to be in a community"' (2001: 1); it is "a 'warm' place, a cosy and comfortable place" (2001: 1) and somewhere "we can count on each other's good will" (2001: 2). Although many scholars have recognized the potential of communities to exclude (Yuval-Davis 2006a; Karner and Parker 2011), with members socialized to discern particular boundaries demarcating themselves from others (Cohen 1985; Crow and Allan 1994), Bauman's point is broadly held: Communities (including religious communities) are widely associated with notions of mutual support, social interaction and shared belonging (Bellah et al. 1985; Putnam 2000). Moreover, and of particular relevance to the present study, to Bauman, communities in general are constructs that seek to offer "security," even if this necessitates a certain loss of "freedom" (2001: 4). Addressing the instabilities wrought by processes of globalization (not least migration) alongside principles of cosmopolitanism and multiculturalism, Bauman notes that "[n]owadays, community is sought as a shelter from the gathering tides of global turbulence-tides originating as a rule in faraway places which no locality can control on its own" (2001: 142). However, he warns against "[t]he construction of walled-up communities [which] does nothing to close that gap ... Instead of aiming at the sources of insecurity, it channels attention and energy away from them" (2001: 143). In this way, he acknowledges the potential of communities to divide and distinguish groups into an "us" and a "them," which he contends that rather than ensuring security, actually makes them "easier targets" for globalizing forces (2001: 143). These ideas, I argue, are applicable to many places of worship today. However, whereas Bauman and others (e.g., Beyer and Beaman 2007; Kong and Woods 2016) consider the ways in which many communities negotiate the influence of broader globalizing trends, I want to focus here on the more tangible risks to religious communities. For this reason as well as to increase methodological clarity, in this article I define a Jewish community similarly to Buckser (2000) as a specific Jewish congregation and the families and individuals formally affiliated with it, rather than more generally as a distinct population with associated social infrastructure which has congregated in a particular location (e.g., Kudenko and Phillips 2009; Sheskin and Hartman 2015), or alternatively as a global diaspora (Boyarin and Boyarin 1993; Dwyer et al. 2013), as also used in the existing literature.

Surprisingly, previous scholarship has scarcely scratched the surface of the challenges posed by security issues to religious communities in general, let alone Jewish communities specifically. Certainly, where security has been scrutinized with respect to religious groups, it is almost invariably framed in terms of protecting 
wider society from religious-especially Muslim-extremists (e.g., Brown 2008; O'Toole et al. 2012), rather than of safeguarding worshipers and other attendees from hate crimes. ${ }^{1}$ The implication is that religious institutions represent spaces that are potentially dangerous to the outside world, without considering these sites' own susceptibility to attack. Moreover, despite offering some useful findings concerning the distribution of arson attacks in particular, the small number of studies that have considered security threats to places of worship in the U.S. context ${ }^{2}$ remain largely limited to a small number of Christian denominations (e.g., Soule and Van Dyke 1999; Bartkowski et al. 2002). Bourns and Wright (2004) have explored a wider range of crimes, including vandalism, theft and violent attack, but again, their study is limited to just two Protestant denominations, and their attention predominantly centers on the challenges faced by clergy within rather than beyond their communities. Furthermore, in a more recent study of religious communities' adoption of security measures (Scheitle and Halligan 2018), the voices of religious actors regarding victimization risk are necessarily constrained by the fixity of the survey design, which does not allow individuals to fully express their perspectives toward such issues. Scheitle and Halligan's (2018) investigation additionally focuses on general factors such as organizational size, resources and previous experiences of crime as determinants of security measures rather than addressing differences by religious groups. The main contribution to understanding Jewish congregations' engagement with security concerns has recently been made by Scheitle and Ulmer (2018), who through interviewing informed figures at a range of religious communities in the American Midwest, present various ways in which these institutions seek to balance being opening and welcoming on the one hand and safe and secure on the other. They find that Jewish congregations generally "show the most complexity in regards to thinking about security" (2018: 34), but prioritize general themes across religious communities rather than centering on the distinct issues faced by any one faith group. Given the unique history of antisemitism and Jews' changing place in American society (for historical overviews, see Brodkin 1998; Diner 2004; Goldstein 2006), it is thus necessary to extend such scholarship to focus specifically on Jewish communities' negotiation of this dilemma.

Indeed, as Frank (1997: 739) argues, despite many American Jews' ability to "enjoy white privilege in most institutional spheres, such as employment, housing, education, credit, and health care," their whiteness can be described as "ambiguous" given their continued vulnerability to antisemitism (see also Biale et al. 1998; Weisskirch et al. 2016). For instance, in addition to the three recent attacks on places

\footnotetext{
${ }^{1}$ In the present study, a hate crime is defined as a "criminal offense against a person or property motivated in whole or in part by an offender's bias against a ... religion" (FBI, no date).

${ }^{2}$ Furthermore, in spite of the fact that security measures have long been common in synagogues and other Jewish institutions in much of Europe and Latin America (Hinshaw and Bisserbe 2018; Stavans 2019), where a number of high-profile attacks have occurred during the last 40 years, scholarship detailing their adaptations remains scarce. Greater attention has instead been paid to the general architecture of synagogues (e.g., Krinsky 1985; Coenen Snyder 2008; Verkaaik 2014) and broader political and sociocultural (e.g., Knudson 1972; Elkin 1985; Bokser Liwerant, 2007; Israeli 2009) dynamics in these societies.
} 
of worship mentioned at the start of this article (following a much longer historical precedent), one can point to the latest FBI data for hate crimes in the U.S., which reveal that of the 1175 reported victims of anti-religious hate crimes in 2019, as many as $60.2 \%$ were the victims of anti-Jewish bias (FBI 2020b). The strategies undertaken by many American Jews to increase their safety, such as choosing to live in predominantly Jewish neighborhoods (Alper and Olson 2011) or not publicly disclosing their religious affiliation (Cutler 2006; MacDonald-Dennis 2006), also demonstrate an ongoing feeling of susceptibility, at odds with the seemingly popular notion that Jews constitute part of the country's white hegemony (see Dominguez 1994; Freedman 2012), even before one considers the significant proportion of American Jews who identify as people of color. ${ }^{3}$ Consequently, dedicated research into Jewish congregations' consideration of security risks is imperative.

Although I do not analyze DeLillo's White noise in detail here, I believe that the novel's title encapsulates the dilemma of balancing community and security faced by Jewish institutions. White noise explores a number of themes relevant to questions of securitization, religious communities and prejudice, from its characters' ingrained fear of death to their desire to find a group identity, and from the narrator Jack Gladney's work as the department chairman of Hitler studies to a postmodern society "where nuns no longer believe in God" (Ferris 2007: no page number). Whereas DeLillo uses the idea of "white noise" to encapsulate the ubiquity of background sounds that constitute the modern world, I use it to depict how security is part of the backdrop of synagogues today, required in order to function as desired and yet also at constant risk of undermining the warm ambience desired by members of the community. Moreover, not unlike DeLillo's usage, I regard the pervasiveness of white noise as an effective metaphor for people's constant vulnerability in synagogues, with securitization accordingly providing an unintended reminder of one's susceptibility while aiming to assuage those very feelings. Finally, the fuzziness of white noise encapsulates the difficulty of drawing boundaries in synagogues - a key aspect of defining communities (Cohen 1985)—whether between "secure enough" and "overly secure," or between "safe" and "unsafe" people. While analyzing my interview data, the concept emerged as a concise way of articulating the overall dilemma and associated predicaments expressed by the interviewees, with the research process described in the following section.

\section{Materials and Methods}

Previous studies of securitization and places of worship have tended to utilize quantitative methods in order to ascertain religious institutions' perceptions of vulnerability and (generally associated) adoption of security measures (Scheitle and

\footnotetext{
3 Due to inconsistencies in sampling methods and questions across surveys, figures remain uncertain, with the Pew Research Center (2013: 46) estimating that this population represents 6-7\% and Kelman et al. (2019: 2) as many as $12-15 \%$ of the American Jewish population. Dashefsky and Sheskin (2020) suggest that the true percentage is probably closer to the former but expect it to increase in the future.
} 
Halligan 2018), to gain a snapshot of violent events (Bourns and Wright 2004), or to relate previous attacks against a series of variables (Bartkowski et al. 2002; Soule and Van Dyke 1999). However, given the likelihood that individuals hold widely varying perspectives and experiences of security concerns, rooted in unique places and potentially differentiated by religious identification, as well as the fact that security and securitization are social constructions (Malmvig 2005), qualitative methods appear preferable in revealing this subject's inherent nuances, as Scheitle and Ulmer (2018) have started to tease out. Qualitative methods are also better suited to exploratory research such as this, as surveys (for instance) risk applying normative categories that reflect the researcher's assumptions rather than offering the necessary space for individuals to express their own perspectives (Samson et al. 2018). Accordingly, semi-structured interviews were used in order to allow respondents to express their concerns, explain their strategies and identify issues of personal importance with far greater freedom than methods such as surveys would have permitted. Ethical approval for this project (Research Protocol \#MS111219GEO-R1) was granted by DePaul University's Institutional Review Board (IRB).

Chicago was selected as the study location not only due to the author's familiarity with the city, but crucially because the preponderance of religious institutions in general here would facilitate their anonymization, which was especially desirable given the sensitivity of the subject matter. Potential interviewees were identified by compiling a list of places of worship meeting the following criteria: located in Chicago or its suburbs; contact email address or online form clearly presented on website; and lacking obvious uniqueness to a reader, such as by representing the only specific branch of a religious group in the city. Applicable places of worship were contacted either via email or the online form connected to the institution's website. Although this research elicited the views of a range of religious leaders in Chicago, representing Judaism, Catholicism, Islam, Buddhism, Hinduism, and mainline and evangelical Protestantism, the data presented here are all from the interviews undertaken with Jewish leaders (four one-on-one interviews with rabbis, plus a focus group interview with the rabbi and two community directors of a synagogue, totaling seven respondents across five interviews), given that it quickly became clear that their engagement with security issues was highly distinctive and their experiences similar. Indeed, although the sample of Jewish respondents was small and thus it is difficult to claim that it was representative, there were many consistencies across the interviews as well as with Scheitle and Ulmer's (2018) findings, and so it is fair to assume that a reasonable amount of saturation was achieved. The interviews were conducted either in person at the synagogue in question or over the phone, between January and March 2020, and generally lasted between 30 and 45 minutes. All of the Jewish leaders agreed to be audio-recorded.

After first inquiring into the synagogue's background (such as in terms of its mission, membership and community functions), in part with the aim of easing each interviewee into the research process, I sought to develop a thorough understanding of the security issues faced and the ways in which the community in question has responded. Inductive coding was used to analyze the interview transcripts, initially revealing general themes such as "affected by security concerns" and "finding a balance." Through subsequent readings of the transcripts, 
these broad codes were refined (Saldaña 2013), producing new codes that form the basis of the upcoming analysis, specifically "avoiding a fortress mentality," "appreciating intersectional identities" and "secularizing trends." In the following analysis, the movements represented are not detailed, and the three abovementioned focus group respondents are subsumed as one synagogue community in order to reinforce their anonymity. The first and most fundamental predicament highlighted by the respondents was ensuring that security concerns do not turn one's synagogue into a fortress, as the first results subsection elucidates.

\section{Three Predicaments}

\section{Avoiding a Fortress Mentality}

Encapsulating the diverse and distinctive threats faced by synagogues in merely one city, the Jewish respondents described their experiences of a range of hate crimeseither firsthand at their current location or at a previous position, or at a nearby place of worship-including vandalism, bomb scares, suspicious packages and arson. Although similar issues were raised by a Muslim respondent in the broader study (Samson 2020), for the other community leaders, problems that appeared to be less specific to religious communities - such as burglaries, robberies, cyberattacks and local traffic dangers-were generally more significant, despite my questions largely attending to hate crimes. This disjuncture in what one even means by "security" exemplified the different religious groups' status in American society (Samson 2020), with the Jewish leaders invariably feeling a greater sense of vulnerability based on past experiences. Furthermore, in response, synagogues have taken particularly significant steps in the hope that their community members can both feel and be safe, for instance: developing and refining exit plans; shutting off certain entryways and only unlocking selected doors before, during and after services; increasing security staff (mainly professionals, often former or off-duty police officers); using metal detectors at entrances; supplying staff with panic buttons and walkie-talkies; conducting drills and evacuations among staff; incorporating reinforced doors and bullet-proof windows; and adding physical obstacles such as bollards, boulders and trees around the exterior to reduce the risk of a driver ramming a vehicle into the building or people. Although many of the other religious institutions considered also apply some of these strategies, it is noteworthy that several continue to solely rely on volunteer members as security staff, or have made minimal changes to their security policies despite the occurrence of several high-profile attacks on places of worship in recent years (for further details, see Samson 2020).

Certainly, increased security may seem like a logical response. However, in the case of religious buildings like synagogues, securitization is not in itself sufficient. Religious communities generally seek to be warm and welcoming and, especially for minority groups, a critical mass of co-religionists may enable individuals facing discrimination in the wider society to find comfort and safety (Alper and Olson 2011; McLoughlin 2005). The current feeling that religious spaces may in fact be sites of danger has thus stimulated Jewish leaders to reconsider what a safe synagogue looks 
like: How can one's community be both safe emotionally in the sense of conviviality/congeniality and amiability, and physically, that is, secure from attack? According to almost all the respondents, this balancing act constitutes the key challenge ${ }^{4}$ :

Are we messaging people that maybe this isn't a good place to come? ... It is a challenge, being warm and welcoming, but also being responsible and secure; it's almost like an oxymoron sometimes, and I kind of feel like that's the biggest challenge. [....] If your first experience of the congregation is a guardhouse, that's a statement in and of itself. (Synagogue 1)

I think synagogues and churches, you've got to live with this tension of wanting to be totally open, but now understanding that you can't be totally open, and there's got to be some sort of secure procedures, or security filters, to allow people not only to feel safe, but, in actuality, to be as safe as they can be. (Synagogue 2)

A common word used to describe the excessive form of security to be avoided was "fortress," this being viewed as contradictory to religious institutions as spaces where people can develop trusting relations with one another. Indeed, the respondents, while conscious of the importance of security in general, were also generally keen to ensure that this does not compromise the warmth they can and should provide (see also Scheitle and Ulmer 2018):

Having to have an armed guard is nerve-wracking, and people will jump right to conclusions: "Oh, we're going to be an armed fortress," [... but] we'll find a way to be hospitable. We'll find a way to be welcoming. We'll find a way not to be an armed fortress, even if we are. (Synagogue 3)

The building is an envelope to serve beyond itself, not just a fortress against the world. (Synagogue 4)

Certainly, these security measures were deemed necessary but far from ideal, given their somewhat ominous connotations and restricting of people's ability to come and go as they please:

It's not nice to have to buzz to get into a building on a Friday night for worship services [...] we lock our doors all the time now, and that was not the case when I first came here, and I kind of went into that kicking and screaming, because I don't think that it's very welcoming for people to encounter a locked door when they come in, but I appreciate people's security concerns. (Synagogue 5)

The predicament was said to be particularly acute on occasions such as major holidays that attract large numbers of people, some of whom may be unfamiliar to most community members and security staff due to their infrequent attendance. Many

\footnotetext{
${ }^{4}$ It is worth noting that this balancing act was also described by almost all the participants in the broader study, reflecting a shared sense of vulnerability and solidarity across religious communities, even if the Jewish and Muslim respondents were the most concerned and had accordingly operationalized the most comprehensive strategies; see Samson (2020) for further details.
} 
synagogues also offer a variety of functions other than worship, such as by providing interfaith programs, charities and assorted leisure activities throughout the week, or welcoming school groups and other visitors. In addition, life-cycle events were accentuated as times when people from beyond the regular community enter the space. On all these occasions, it is crucial to find the right balance, scrutinizing unfamiliar people who are attending for entirely inoffensive reasons without subjecting them to a hostile cross-examination:

At least $60 \%$ of the people who come on the Sabbath are a pretty consistent group. But maybe $40 \%$, maybe more, are new. They're visitors. You have a naming ceremony, or any other kind of life cycle event. Funeral. Chances are, $80 \%$ of the people, $90 \%$ of the people, are visitors. There's no way to know who's walking in the door. (Synagogue 1)

To assuage congregants' fears of entering a potentially risky environment, or one that precludes any feeling of comfort, certain simple measures are operationalized to distract attendees from the fact that they are entering highly secure buildings. The most common is ensuring that alongside the (typically) professional security staff who stand at the doors - in some cases in plainclothes in order to appear less threatening to congregants and less conspicuous to a potential assailant-are community members who can welcome attendees in person and provide a friendly face. Thus, even though congregants are inevitably scrutinized on entry and their belongings inspected, a balance can be found between safety and geniality.

Indeed, the general feeling intimated was that people want to know that there is security in place to keep them safe, but they do not want to see it as such. In this way, security was deemed necessary, but necessarily invisible, with a balance achieved by providing people with the authority to tackle a situation should it arise who nonetheless operate largely outside of the attention of the people they are protecting. However, this raises a further problem: Despite seeming like the opposite of the much-maligned "security theater" 5 described by Schneier (2009), given that security is disguised within the community fabric rather than being overt, it is because congregants know that security is in place that they feel safe enough to attend, even though in reality, full protection against an attack is impossible to guarantee. One Jewish leader explained this issue as follows:

A lot of it is just "security theater." The truth is, if somebody wants to hurt us, there's nothing that's going to stop them from hurting us ... unless we're going to be in fortified buildings and figure out a way for people to get in and out that nobody's going to see, we're not going be safe. (Synagogue 5)

Certainly, no matter its publicness, any form of security-coupled with the decision of those who are potentially vulnerable to assemble in a place that is also potentially vulnerable_can be regarded as at least partly a performance (Butler

\footnotetext{
5 Schneier (2009, no page number) defines "security theater" as "security measures that make people feel more secure without doing anything actually to improve their security."
} 
2015), providing a statement that a building like a synagogue is worthy of protection in the face of genuine or perceived danger.

It is also important to note that security was said to have become normalized in synagogues to such an extent that it is now part and parcel of contemporary synagogues' functioning and their stakeholders' daily conversations. Those who choose to continue attending must accept that it is a necessity, even if they would prefer it not to exist (see also Scheitle and Ulmer 2018). Indeed, according to the Jewish leaders, it is impossible to return to a situation in which security is not perceived as critical:

I don't know if we can ever go back. That's what bothers me about instituting these changes. Like, once you lock the doors, what has to happen to say it's safe to unlock them again? (Synagogue 5)

I think, for many folks of a certain level of attainment, it's normal now. And isn't that the sad thing ... the problem is that we are getting used to these [security measures] as necessary preconditions for an institution to function. (Synagogue 4)

Frankly, if we decided tomorrow to go back to the security that we had in 2000, I'm not sure I would come into this building. So, that says a lot. In other words, people pay attention today. (Synagogue 1)

Certainly, it was said that without security, there is a significant risk that people will not attend services and events will not take place, demonstrating how it has become the facilitator of community life:

Security has become, really, part of the rhythm and part of the work of the congregation. We don't plan any programs without security. (Synagogue 1)

I think it's an issue that allows you to do the other things that you want to do. So I think it's baked in, as opposed to, "Security is job one." It's, "What's our job? How does security help us do that?" (Synagogue 4)

Nevertheless, despite the seemingly severe connotations of security being at the center of synagogues' activities, some positive outcomes were also identified by the respondents, exemplifying the resilience that religious adherents and communities develop in response to threats (Gunnestad and Thwala, 2011; Joakim and White 2015). These particularly revolved around parents, who due to their concerns for their children's safety, often now spend greater time engaging in these community spaces:

I've seen more parents hanging out in the building when we have our kids here ... this is actually kind of positive, to have the parents in the building, [in the past] there were more people just dropping off before on Sunday mornings, and now many of them are staying through, and having a bagel and cup of coffee while their kids are here. (Synagogue 5)

Moreover, given the ongoing COVID-19 pandemic (which forced Chicago into lockdown from March 2020, after I had conducted all of the interviews presented 
here), synagogues and other community buildings are now being compelled to adapt in other significant ways, which may help render security a less obviously intrusive concern. Also in need of consideration are the diverse ways in which security staff are viewed by congregants, as such authority figures may not be regarded as entirely unproblematic either. The following subsection explores this predicament by acknowledging the importance of appreciating attendees' intersectional identities.

\section{Appreciating Intersectional Identities}

The predicament of balancing security and community was deemed particularly salient with regard to two minority groups within many Jewish congregations: people of color and LGBTQ+individuals. This research was conducted prior to the infamous killing of George Floyd, an African American man, by a white police officer in Minneapolis, Minnesota on May 25, 2020 (Deliso 2020), triggering protests for police reform and racial justice in the U.S. and abroad, but Chicago and many other major American cities have a much longer history of controversy regarding police accountability, especially in relation to the heavy-handed treatment of Black individuals (Citizens Police Data Project 2020). Consequently, security was said to be a particularly touchy issue for individuals who have had negative experiences of being racially profiled by authority figures:

I think some people have grown to appreciate the importance of the officers, and there are others who sometimes cast a suspicious eye ... there have been situations in the past, with visitors and/or Jews of color, sometimes being treated less warmly, if they come across as strangers ... sometimes people just automatically assume, "You're a cop, so, you know, you're going to be violent to Black people," or something like this. (Synagogue 3)

I haven't seen it, but I feel like ... there might be some low-key profiling that happens ... of African Americans who are given the side-eye when they're coming in, or asked extra questions that other people wouldn't be asked. (Synagogue 5)

Fernheimer (2009) demonstrates how various groups who may be termed "Black Jewish" are compelled to negotiate Ashkenazic hegemony, often being requested to "authenticate" their Jewishness due to having an alternative Jewish ancestry, and regularly seeing their claims to this identity denied or impugned. Fernheimer contextualizes this development by highlighting how the first significant growth in African Americans claiming Jewishness occurred at a time when "recognized Jews" were attempting to rapidly progress in American society, rendering the latter unwilling to admit Blackness as congruent with Jewishness lest it compromise their own, still inchoate, "white" American identity. Indeed, community boundaries are often difficult to clearly define, with broadly defined groups such as Jews in reality characterized by considerable diversity, despite some attempts by more powerful groups to present Jewishness and its boundaries as fixed (Rohrbacher 2016; see also Cohen 1985). The widely reported existence of tensions between (Ashkenazi) Jewish and African American communities in the past half-century 
(Ginsberg 1993; Rose 1994; Greenberg 2006) only appears to have reinforced a popular notion of "Black" and "Jewish" being incompatible. Thus, in addition to seeing their Jewishness refuted, Jews of color are at potential risk of being treated as a threat to Jewish congregations.

Puar (2007) has shown how securitization has also proven to be a controversial issue among LGBTQ+individuals-not least those who are also from racial and ethnic minority backgrounds - as select homonormative ideologies are incorporated into the heteronormative mainstream to distinguish "upright" from "perverse" queer subjects, resulting in a "pinkwashing" of violence, a commonplace misreading of identity, and a pathologization of minority bodies. Given these dynamics, it is unsurprising that the presence of security staff at sites that are intended as safe spaces can create discomfort among members who are apprehensive about these individuals' professionalism:

I think that people of color who are being watched are, in many ways, more sensitive, and with cause, than people who are white. People who are part of the LGBTQ community are [also] going to be more sensitive to being watched. (Synagogue 1)

Certainly, according to some of the respondents, Jewish communities as well as their security staff must work hard to ensure that Jewish minority groups feel welcomed and recognized as fellow Jews by their peers. In this way, they demonstrated an appreciation of the importance of recognizing their congregants' distinctive experiences of inclusion/exclusion and the need to treat people equitably:

We're evolving. We're learning. We're just trying to be the best community we can be. We've also done a great deal of sensitivity training with our security staff, and we've brought people from the outside to do training with the entire staff. How do we refer to people? How do we engage them? And I think we've come a long way, and I want to say that our security staff has been remarkable in their openness and willingness to learn, and to be as professional as anyone could ever hope for. (Synagogue 1)

What I don't want to do is just lay that [racial profiling] on the police officers that are here. It's an institutional issue, because we seek to be more inclusive of our diversity. We recognize we [all] have to practice at it ... the good news is that we, as an organization, are trying really hard to recognize the work that has to go into being inclusive of our diversity, and eventually I think we'll have important opportunities to practice that inclusion. (Synagogue 3)

Relevant here is intersectionality theory, which despite some variations in its conceptualization, emphasizes the interconnections that exist between different identities and the ways in which these may reinforce one another, and in the process challenges any notion that they can be homogenized (Crenshaw 1991; McCall 2005). By attending to these intersections, it may be feasible to gain a greater understanding of individuals' lived experiences of inclusion and exclusion in complex contexts (Yuval-Davis 2006b; Valentine 2007). There is also the possibility that security 
issues help render questions of accountability more tangible to many people, stimulating conversations regarding how best to improve community relations more broadly:

We care about them [the officers]. We care about their lives. We talk with them. We create interesting connections. And, by the way, interestingly enough, it complicates subjects like police accountability, and things, you know, where police make mistakes out in the field, right? It's hard, because, you know, there's that, sort of, like, "Hey," you know, "police need to be accountable," and we know a bunch of police officers who are our friends, and they do a great job, and may or may not be contributing to the problems that you hear about on the news, so it becomes a really interesting dilemma, kind of from a justice standpoint, and how we can kind of do both, right? Support these officers who support us and keep us safe, and stand up for things that we may think need attention. You know, like police accountability. (Synagogue 3)

In line with the strategy of encouraging security staff to simultaneously welcome attendees mentioned in the previous subsection, employing the same individuals as security staff and requesting that they converse with community members when possible was deemed the optimal solution, enabling individuals to familiarize themselves with one another's faces and ideally names. Ultimately, the hope articulated was that despite their differing purposes of being in a Jewish community space and the possibility that their relationships have been frayed in the past, attendees and professional security staff can recognize that their primary concern-to be able to attend in safety and comfort-is the same. The following subsection addresses the final predicament identified for synagogues: ensuring that securitization does not intensify broader secularizing trends.

\section{Responding to Secularizing Trends}

It is important to state at the outset of this subsection that understandings of secularization and whether the theory is relevant both to the U.S. context (Berger et al. 2008; Voas and Chaves, 2016) and Judaism (Buckser 2011) remain highly contested. Nevertheless, two of the three elements famously identified by José Casanova (1994) as evidence of secularization should be regarded as applicable to the issues raised by the Jewish leaders in this study: privatization, pertaining to religion's marginalization as an increasingly private rather than public matter; and decline of religion, referring to a diminution in religious belief and/or practice, in this case the latter.

Privatization was particularly apparent. Indeed, in line with Scheitle and Ulmer's (2018) finding that in order to reduce their vulnerability, some U.S. mosques seek to be as inconspicuous as possible, such as by avoiding putting any signs or distinguishing indicators on their exterior, the Jewish leaders articulated a growing need to limit their public presence. In some cases, this simply took the form of no longer publicly advertising their events, lest they attract an individual with malevolent objectives: 
People have told me that, you know, they're scared when they come here, and there are big events that are publicly advertised. People want us to advertise publicly less. (Synagogue 5)

When we're thinking about a particular event, and the extent that we wish to publicize it in the community, the hope is that we'll bring new people in, who haven't been here before. The fear is, some bad guy's going to see it, and say, "Oh, this is a good time to go and do some damage." And so, the publicness of our events is weighed against the security concerns, fears, whatever, and different people within the congregation, within the staff, are more cautious, and some less cautious, so they would go on this side of the balance or that side of the balance. (Synagogue 2)

Doing so was said to have two interrelated purposes: functionally, a potential attacker would be less likely to identify their building as a synagogue, especially important on days that attract larger numbers of congregants; and intuitively, congregants would be enabled to feel more confident that they are safe from threat. Similarly, whereas in the past some of the synagogues would offer outdoor activities in public spaces, especially in the summer, these are now widely discouraged:

We have done stuff outside, and it's a bit nerve-wracking ... we were very vulnerable ... I was happy when we finished. Nobody got hurt ... nobody got, you know, shot up at, so. (Synagogue 3)

However, a plausible implication of making community events more private is that the engagement of some members, perhaps especially those who are more "loosely" connected (Wuthnow 1998) and do not keep close track of the opportunities available at their congregations, will decline further, whether to diminish their own vulnerability or because the larger, more public events that previously attracted them are no longer deemed feasible.

The financial costs required to securitize synagogues may intensify this dynamic, and raise the additional issue of decline of religion (however, I will henceforth refer to this as just "decline of practice," given that Judaism typically puts greater emphasis on practice than belief; see Buckser 2011). Such expenses are often partly swallowed by members in their dues, even if certain grants are available from the U.S. Department of Homeland Security and Jewish federations to pay for professional security staff and structural adaptations to buildings such as electronic security doors and bullet-proof windows. Although I did not ask actual and potential synagogue members whether they deem dues to constitute a barrier to involvement, this has been mooted by various observers (e.g., Komaiko 2017; Burton 2018); moreover, one study has found that synagogues that have adopted a voluntary dues model are seeing rises in membership and congregational engagement (Reisner and Judson 2017). Certainly, in a contemporary context that is often described as a religious "marketplace" (Lazerwitz et al. 1998; Roof 1999; Kaplan 2009) in which religious institutions compete for adherents and income, additional expenses may limit synagogues' desirability to many. One demographic that seems likely to be significantly affected by increased costs due to security is single young adults, this group already 
often regarded as the least likely to associate with a Jewish institution (Cohen and Kelman 2007; Kaplan 2009; Shain et al. 2013). Indeed, a Jewish leader highlighted the difficulty of promoting a synagogue that requires dues to young adults who can engage in Jewish life for little to no cost through programs such as Birthright Israel and Base Hillel:

It used to be that people would join a congregation because they want to support the Jewish community. Then many people sort of got a fee-for-service mentality, that they're joining a community because they want religious school, or to celebrate bar mitzvah with a kid. Now we're sort of at a stage where people are expecting free-for-service. You know, "I got a free trip to Israel. I'm getting all these other free services in the city that are provided by Base Hillel," whatever it is. "I don't need a synagogue anymore." Or, "I might need a synagogue, but I don't want to pay for it." So, that financial model is changing, too ... I'm not sure what it's [Birthright Israel] doing in terms of people's relationship with the finances of the Jewish community when a couple of billionaires are funding everything. (Synagogue 5)

Thus, although other factors are at play in shaping an individual's interest in affiliating with a synagogue (as the Jewish leader acknowledged), security costs seem likely to further compromise some people's willingness to become members or to continue engaging, especially when the perceived risk of congregating examined above is also taken into consideration. Even though only a few respondents identified specific examples of members using security threats as a reason to dissociate, this was widely perceived as a dynamic that may exist, especially since the shooting at Tree of Life in Pittsburgh:

I'll give you an extreme example - and thank God this is the extreme - of a couple who decided not to come because it was too dangerous for Jews to gather in significant numbers [... so] they don't come. Still support the institution, but don't come. (Synagogue 4)

I think, after the shooting in Pittsburgh, some people pulled back. I think that they've started to come back. I think people are very cautious in the building. (Synagogue 5)

A qualification should be made that "there's a meaningful percentage of people that don't need much of an excuse to walk away from religious institutions" (Synagogue 4), but it is still necessary to acknowledge that security issues are exacerbating the challenges faced by many religious institutions today in attracting individuals in a society in which religion is increasingly perceived as one option among many (Taylor 2007). Crucially, this issue may be self-reinforcing, as should individuals disengage, a synagogue will draw upon less money in dues and be more limited in its ability to provide activities that rely on a particular critical mass of people, potentially entrenching its struggles to attract members. For instance, the increased costs that security entails constrain synagogues' abilities to provide other functions, such as part-time education, of particular concern to parents and those seeking an extra income: 
Security absolutely impacts our bottom line, because if we're spending $\$ 50,000$ a year for security, that's, gosh, ten fewer religious school teachers, or it's, you know, a part-time office position. Or, you know, it's \$50,000 we're not spending on something else. (Synagogue 5)

Nevertheless, it is also plausible that synagogue communities will become more rather than less devoted, as only the most committed members are likely to choose to continue attending:

Now, many congregations ... have added on, basically, a security surcharge to the dues. And, by and large, people, I wouldn't say they're happy to pay it, but they pay it. And the ones who don't pay it are the ones who are due to leave anyway. I've not heard of anybody saying, "Well, this is not important. I'm not going to pay it." They understand the importance of it. (Synagogue 2)

Given the exploratory nature of this study, further research is necessary to examine the implications of securitization for questions of secularization, but it appears highly plausible that synagogue communities will become smaller yet more committed, as those individuals who are ambivalent about congregating in nominally public spaces will choose instead to practice in private spaces like the home, if at all. Along with proposing relevant areas in need of additional scholarship, the following discussion synthesizes this study's findings and explains how securitization has become synagogues' "white noise," invisible, necessary and yet inherently ambivalent.

\section{Discussion}

This study has explored how within the context of recent fatal attacks on places of worship, synagogues are attempting to find a balance between being warm and welcoming on the one hand and safe and secure on the other. Through examining the challenges of creating community in an insecure social context, it builds on Bauman's (2001) appraisal by offering an empirical analysis of places of worship in Chicago. Crucially, whereas Bauman argues that "community" is principally invoked when individuals feel threatened or alienated, this study finds that for many religious individuals, congregating as a community may actually engender feelings of insecurity and provide a reminder of one's vulnerability. Indeed, the article has highlighted how for synagogues, securitization is far from simply a matter of maximizing a building's security measures; being seen as a place that can offer warm, cozy feelings, especially relevant in an often-turbulent world (see Bauman 2001), is also essential. Thus, securitization for synagogues means finding a compromise between physical and affective aspects, presenting an inherent dilemma that renders security a necessary evil.

In this discussion, I will explain why I believe "white noise" is an effective metaphor for the securitization of synagogues. First, in the most conventional use of the phrase, white noise refers to indistinct background sounds that create an ambience but that largely exist beyond the forefront of our consciousness. This encapsulates 
how security does (or should) operate within synagogues: it is "there" even if it is not obvious, and it helps communities to function because without it, events and activities cannot or do not proceed. Thus, it has become a fundamentally normal component of synagogue life, and one that is difficult if not impossible to relinquish in the future, even though this may seem desirable.

Second and relatedly, should it become too obvious, security risks undermining the warm ambience coveted. Indeed, part of the irony of the dilemma is that security offers protection while simultaneously providing a reminder of one's vulnerability and mortality. The optimal form of security emphasized by the respondents is thus one that can keep people safe but that people do not view as security. Building relations between security staff and congregants, for example, was regarded as critical to developing trust not only in the people employed as a means of protection, but also in the synagogue's ability to balance safety and community. Plainclothes security staff and volunteer lay members of the community offering a friendly face on entry can provide an effective compromise, as they are not necessarily seen as security (with all its severe connotations) even while they provide eyes over the congregation. People do not want to see security, as it implies that there is a risk involved in attending a synagogue. This notion of invisibility being preferable renders a phrase lacking an unequivocal visual component, like "white noise," appropriate.

Third, the metaphor's implicit ambiguity encapsulates the fuzziness of boundaries and the associated difficulty of constructing them in synagogues, despite boundaries being fundamental to defining communities (Cohen 1985). One such boundary must be found between "secure enough" and "overly secure" as explained above; in other words, ensuring the security of the community without this becoming undesirably conspicuous. The other boundary in need of demarcation is between "safe" and "unsafe" people. With regard to regular attendees, this should generally be unproblematic; more difficult are cases of irregular or one-time visitors whom are not known to many or any of the community and their security staff. Of course, most people within this group do not pose any threat to religious communities and consist of members and other attendees at a particular service, event or meeting, family and friends visiting for a life cycle event, and school groups, among others. However, there is always the risk that an individual or group with malicious intentions will attend, and it is such people who must therefore be identified as quickly as possible. The examples of recent fatal attacks on U.S. synagogues and other places of worship mentioned at the start of this article provide tragic evidence of the importance of effectively distinguishing between "safe" and "unsafe" people: For instance, the perpetrator of the Emanuel African Methodist Episcopal Church shooting in Charleston managed to avoid raising suspicions for as long as 40 minutes before opening fire (Shah 2017).

The article has also highlighted other dilemmas inherent to the securitization challenge. For example, the presence of security staff at synagogues has multifaceted implications for different people within a religious community, especially where individuals have had injurious encounters in the past. In the Chicago context, this was described in terms of tense race relations between white police officers and Black congregants, racial profiling being identified as an issue that may occur at the entrance to synagogues, which in its own way renders "white noise," with 
its implications of white preeminence, lamentably apt. Although conversely individuals may be enabled to build trusting relations and potentially discuss issues of accountability through their increased contact, there is the possibility that the latter's comfort within their communities and even their willingness to attend will be undermined. How best to welcome those whose connections are "loose" (Wuthnow 1998) presents another challenge, because although the Jewish leaders were adamant that their most committed members' practices will not be affected, it is possible that occasional attendees - who in some cases, constitute the majority of members-will withdraw, especially from any activities that seem too "public." Additionally, as a means of considering the conceivable link between securitization and secularization identified here, further research should aim to ascertain members' perspectives in order to elucidate these issues. Indeed, it is plausible that attendances will shrink, but the general level of attachment will increase, as only the most devoted will congregate. For instance, although parents were often said to be concerned about the safety of their children, rather than withdrawing them from the educational and community activities on offer, some now choose to stay in the building and socialize as well. By contrast, young single adults were perceived as a difficult group to continue engaging, in part due to the increased membership dues necessary to cover the additional security measures taken. The conclusion points to areas in need of further investigation, based on this study's contributions.

\section{Conclusion}

Synagogues and other Jewish community institutions (and indeed many places of worship in general) are currently challenged with the dilemma of finding a balance between security and community. This article has identified three predicaments that collectively constitute this larger dilemma: avoiding a fortress mentality, by which one's community becomes so defensive that social bonds are undermined; appreciating intersectional identities, in order to ensure that potentially marginalized individuals feel welcomed; and responding to secularizing trends, specifically the apparent privatization of Jewish practice and community compelled by security concerns, and the possible decline of practice at synagogues exacerbated by increased dues. I have described this overall securitization dynamic as "white noise," being necessary for synagogues' functioning and yet necessarily invisible, aimed at protecting people from danger yet potentially reminding them of their vulnerability, and defining boundaries even where distinctions inevitably remain uncertain. The longterm implications of this dilemma for Jewish communities remain to be seen, and the COVID-19 pandemic will undoubtedly engender changes of its own, but it is reasonable to expect that in-person communities will become smaller and tighter. It will also be interesting to see whether other possibilities mooted here-such as the increased disengagement of many young single adults-will occur and to what extent security will be deemed a factor.

Certainly, as one of the first studies to examine security issues at places of worship in general, let alone synagogues and other Jewish community institutions more specifically, there remains considerable scope to examine the predicaments 
identified here in other social and geographical contexts. Indeed, although this investigation's findings cannot be generalized to other places_-and as a qualitative study whose findings are necessarily embedded within specific places of worship with unique experiences of responding to varied risks and threats, generalization was not a key aim (see Polit and Beck 2010) — it is plausible that the key dilemma identified of balancing security and community has widespread relevance. At this stage one can note that this issue has also been identified among a range of religious groups by Scheitle and Ulmer (2018) as well as in the broader study (Samson 2020), and research in additional contexts would help build our understanding of whether the white noise metaphor can apply elsewhere. It is expected that contexts where security has long been a significant concern, such as in Latin America and Central and Eastern Europe, have much to offer the discussion. It would also be interesting to explore whether different Jewish movements have been affected in distinctive ways by security concerns, or to examine the role of broader political discourse in shaping Jewish communities' feelings of vulnerability in what may reasonably be described as a polarized and contentious political and social climate across much of the world. In so doing, it will be possible to develop a greater understanding of how Jewish communities are negotiating security threats today, and help them serve all those in need of both security and community.

Acknowledgements I would like to thank the three anonymous reviewers for their perceptive comments and suggestions, Karis Melin for conscientiously transcribing the audio recordings of the interviews, and Euan Hague for providing constructive advice on the original research proposal. I am also very grateful to the Jewish leaders who participated in the research, and DePaul University's Vincentian Endowment Fund Board for generously awarding a VEF Grant to support this investigation (project no. 700321).

\section{References}

Alper, Becka A., and Daniel V. A. Olson. 2011. Do Jews feel like outsiders in America? The impact of anti-Semitism, friendships, and religious geography. Journal for the Scientific Study of Religion 50 (4): 822-830.

American Jewish Committee (AJC). 2020. The state of antisemitism in America 2020. https://www.ajc. org/sites/default/files/pdf/2020-11/The_State_of_Antisemitism_in_America_2020.pdf. Accessed 18 January 2021.

Anti-Defamation League (ADL). 2020. Audit of antisemitic incidents 2019. https://www.adl.org/audit 2019\#executive-summary. Accessed 18 January 2021.

Bartkowski, John P., Frank M. Howell, and Shu-Chuan Lai. 2002. Spatial variations in church burnings: The social ecology of victimized communities in the South. Rural Sociology 67 (4): 578-602.

Bauman, Zygmunt. 2001. Community: Seeking safety in an insecure world. Cambridge: Polity Press.

Bellah, Robert N., Richard Madsen, William M. Sullivan, Ann Swidler, and Steven M. Tipton. 1985. Habits of the heart: Individualism and commitment in American life. Berkeley: University of California Press.

Berger, Peter, Grace Davie, and Effie Fokas. 2008. Religious America, secular Europe? A theme and variations. Aldershot: Ashgate.

Beyer, Peter, and Lori Beaman, eds. 2007. Religion, globalization and culture. Leiden: Koninklijke Brill NV.

Biale, David, Michael Galchinsky, and Susannah Heschel, eds. 1998. Insider/outsider: American Jews and multiculturalism. Berkeley: University of California Press.

Bokser Liwerant, Judit. 2007. Jewish life in Latin America: A challenging experience. Journal of the Rabbinical Assembly. http://www.juditbokserliwerant-unam.mx/artc/20-54\%20Jewish\%20life\% 
20in\%20Latin\%20America\%20A\%20challenging\%20experience\%202007\%20WP.pdf. Accessed 19 January 2021.

Bourns, William, and Wesley D. Wright. 2004. A study of church vulnerability to violence: Implications for law enforcement. Journal of Criminal Literature 32: 151-157.

Boyarin, Daniel, and Jonathan Boyarin. 1993. Diaspora: Generation and the ground of Jewish identity. Critical Inquiry 19 (4): 693-725.

Brodkin, Karen. 1998. How Jews became white folks and what that says about race in America. New Brunswick: Rutgers University Press.

Brown, Katherine. 2008. The promise and perils of women's participation in UK mosques: The impact of securitisation agendas on identity, gender and community. The British Journal of Politics and International Relations 10 (3): 472-491.

Buckser, Andrew. 2000. Jewish identity and the meaning of community in contemporary Denmark. Ethnic and Racial Studies 23 (4): 712-734.

Buckser, Andrew. 2011. Secularization, religiosity, and the anthropology of Jewry. Journal of Modern Jewish Studies 10 (2): 205-222.

Burton, Nylah. 2018. For young Jews joining a synagogue, many barriers exist. Alma. 2 November. Accessed 18 January 2021.

Butler, Judith. 2015. Notes toward a performative theory of assembly. Cambridge: Harvard University Press.

Casanova, José. 1994. Public religions in the modern world. Chicago: The University of Chicago Press.

Citizens Police Data Project. 2020. Cpdp.co.

Coenen Snyder, Saskia. 2008. Acculturation and particularism in the modern city: Synagogue building and Jewish identity in Northern Europe. Doctoral dissertation, University of Michigan.

Cohen, Anthony P. 1985. The symbolic construction of community. Chichester: Ellis Horwood Limited.

Cohen, Steven M., and Ari Y. Kelman. 2007. The continuity of discontinuity: How young Jews are connecting, creating, and organizing their own Jewish lives. 21/64. https://www.policyarchive.org/handle/10207/14574. Accessed 21 September 2020.

Connelly, Eileen A. J., and Laura Italiano. 2018. 11 killed, six injured in 'horrific' shooting at Pittsburgh synagogue. New York Post, 27 October. https://nypost.com/2018/10/27/multiple-people-dead-inshooting-at-pittsburgh-synagogue/. Accessed 21 September 2020.

Crenshaw, Kimberle. 1991. Mapping the margins: Intersectionality, identity politics, and violence against women of color. Stanford Law Review 43 (6): 1241-1299.

Crow, Graham, and Graham Allan. 1994. Community life: An introduction to local social relations. Harlow: Pearson Education Limited.

Cutler, Marianne. 2006. Minority group, majority space: Negotiating Jewish identity in a Southern Christian context. Journal of Contemporary Ethnography 35 (6): 696-728.

DeLillo, Don. 1985. White noise. New York: Viking Penguin Inc.

Deliso, Meredith. 2020. Timeline: The impact of George Floyd's death in Minneapolis and beyond. $A B C$ News, 10 June. https://abcnews.go.com/US/timeline-impact-george-floyds-death-minneapolis/story? $\mathrm{id}=70999322$. Accessed 20 September 2020.

Diner, Hasia R. 2004. The Jews of the United States, 1654 to 2000. Berkeley: University of California Press.

Djelic, Marie-Laure, and Sigrid Quack, eds. 2010. Transnational communities: Shaping global economic governance. Cambridge: Cambridge University Press.

Dominguez, Virginia R. 1994. Questioning Jews. American Ethnologist 20 (3): 618-624.

Dwyer, Claire, David Gilbert, and Bindi Shah. 2013. Faith and suburbia: Secularisation, modernity and the changing geographies of religion in London's suburbs. Transactions of the Institute of British Geographers 38 (3): 403-419.

Elkin, Judith Laikin. 1985. Latin American Jewry today. The American Jewish Year Book 85: 3-49.

Etzioni, Amitai. 1993. The spirit of community: Rights, responsibilities and the communitarian agenda. London: Fontana Press.

Federal Bureau of Investigation (FBI). 2020a. Hate crime. https://ucr.fbi.gov/hate-crime/. Accessed 18 January 2021.

Federal Bureau of Investigation (FBI). 2020b. Uniform crime report: Hate crime statistics, 2019. Washington, D.C.: U.S. Department of Justice-Federal Bureau of Investigation. https://ucr.fbi.gov/hatecrime/2019/topic-pages/victims.pdf. Accessed 18 January 2021.

Federal Bureau of Investigation (FBI). no date. Hate crimes. https://www.fbi.gov/investigate/civil-rights/ hate-crimes. Accessed 18 September 2020. 
Fernheimer, Janice W. 2009. Black Jewish identity conflict: A divided universal audience and the impact of dissociative disruption. Rhetoric Society Quarterly 39 (1): 46-72.

Ferris, Joshua. 2007. In retrospect: Joshua Ferris on White Noise, 19 November. https://marksarvas.blogs. com/elegvar/2007/11/in-retrospect-j.html. Accessed 21 September 2020.

Frank, Gelya. 1997. Jews, multiculturalism, and Boasian anthropology. American Anthropologist 99 (4): $731-745$.

Freedman, Jonathan. 2012. Do American and ethnic American studies have a Jewish problem; or, when is an ethnic not an ethnic, and what should we do about it? Melus 37 (2): 19-40.

Ginsberg, Benjamin. 1993. The fatal embrace: Jews and the state. Chicago: University of Chicago Press.

Goldstein, Eric L. 2006. The price of whiteness: Jews, race, and American identity. Princeton: Princeton University Press.

Greenberg, Cheryl Lynn. 2006. Troubling the waters: Black-Jewish relations in the American century. Princeton: Princeton University Press.

Gunnestad, Arve, and S'lungile Thwala. 2011. Resilience and religion in children and youth in Southern Africa. International Journal of Children's Spirituality 16 (2): 169-185.

Haythornthwaite, Caroline, and Kori Kendall. 2010. Internet and community. American Behavioral Scientist 53 (8): 1083-1094.

Hinshaw, Drew, and Noémie Bisserbe. 2018. For Europe's Jews, worship comes with a heavy dose of security. The Wall Street Journal, 29 October. https://www.wsj.com/articles/for-europes-jews-worsh ip-comes-with-a-heavy-dose-of-security-1540846059. Accessed 19 January 2021.

Israeli, Raphael. 2009. Muslim anti-Semitism in Christian Europe: Elemental and residual anti-Semitism. New Brunswick: Transaction Publishers.

Joakim, Erin P., and Robert S. White. 2015. Exploring the impact of religious beliefs, leadership, and networks on response and recovery of disaster-affected populations: A case study from Indonesia. Journal of Contemporary Religion 30 (2): 193-212.

Kaplan, Dana Evan. 2009. Contemporary American Judaism: Transformation and renewal. New York: Columbia University Press.

Karner, Christian, and David Parker. 2011. Conviviality and conflict: Pluralism, resilience and hope in inner-city Birmingham. Journal of Ethnic and Migration Studies 37 (3): 355-372.

Kelman, Ari Y., Aaron Hahn Tapper, Izabel Fonseca, and Aliya Saperstein. 2019. Counting inconsistencies: An analysis of American Jewish population studies, with a focus on Jews of color. Jews of Color Field Building Initiative. https://jewsofcolorfieldbuilding.org/wp-content/uploads/2019/05/ Counting-Inconsistencies-052119.pdf. Accessed 19 January 2021.

Knudson, Jerry W. 1972. Antisemitism in Latin America (2): Social change in Argentina. Patterns of Prejudice 6 (6): 22-30.

Komaiko, Leslee. 2017. It's too expensive to be Jewish. Los Angeles Times, 30 July. https://www.latimes. com/opinion/op-ed/la-oe-komaiko-cost-of-hebrew-lessons-20170730-story.html. Accessed 18 January 2021.

Kong, Lily, and Orlando Woods. 2016. Religion and space: Competition, conflict and violence in the contemporary world. London: Bloomsbury.

Krinsky, Carol Herselle. 1985. Synagogues of Europe: Architecture, history, meaning. Toronto: General Publishing Company Ltd.

Kudenko, Irina, and Deborah Phillips. 2009. The model of integration? Social and spatial transformations in the Leeds Jewish community. Journal of Ethnic and Migration Studies 35 (9): 1533-1549.

Lazerwitz, Bernard, J. Alan Winter, Arnold Dashefsky, and Ephraim Tabory. 1998. Jewish choices: American Jewish denominationalism. Albany: State University of New York Press.

Lieber, Andrea. 2010. A virtual veibershul: Blogging and the blurring of public and private among Orthodox Jewish women. College English 72 (6): 621-637.

MacDonald-Dennis, Christopher. 2006. Understanding anti-Semitism and its impact: A new framework for conceptualizing Jewish identity. Equity \& Excellence in Education 39 (3): 267-278.

Malmvig, Helle. 2005. Security through intercultural dialogue? Implications of the securitization of Euro-Mediterranean dialogue between cultures. Mediterranean Politics 10 (3): 349-364.

McCall, Leslie. 2005. The complexity of intersectionality. Signs Journal of Women in Culture and Society 30 (3): 1771-1800.

McLoughlin, Seán. 2005. Mosques and the public space: Conflict and cooperation in Bradford. Journal of Ethnic and Migration Studies 31 (6): 1045-1066. 
Obst, Patricia L., and Katherine M. White. 2005. An exploration of the interplay between psychological sense of community, social identification and salience. Journal of Community \& Applied Social Psychology 15 (2): 127-135.

O'Toole, Therese, Daniel Nilsson DeHanas, and Tariq Modood. 2012. Balancing tolerance, security and Muslim engagement in the United Kingdom: The impact of the 'Prevent' agenda. Critical Studies on Terrorism 5 (3): 373-389.

Paul, Deanna, and Katie Mettler. 2019. Authorities identify suspect in 'hate crime' synagogue shooting that left 1 dead, 3 injured. The Washington Post, 28 April. https://www.washingtonpost.com/nation/ 2019/04/27/california-synagogue-shooting-multiple-injuries/. Accessed 20 September 2020.

Pew Research Center. 2013. A portrait of Jewish Americans: Findings from a Pew Research Center survey of U.S. Jews. Washington D.C.: Pew Research Center. https://www.pewforum.org/2013/10/01/ jewish-american-beliefs-attitudes-culture-survey/. Accessed 20 September 2020.

Polit, Denise F., and Cheryl Tatano Beck. 2010. Generalization in quantitative and qualitative research: Myths and strategies. International Journal of Nursing Studies. 47 (11): 1451-1458.

Puar, Jasbir K. 2007. Terrorist assemblages: Homonationalism in queer times. Durham: Duke University Press.

Putnam, Robert D. 2000. Bowling alone. New York: Simon \& Schuster Paperbacks.

Reisner, Lianna Levine, and Dan Judson. 2017. Connection, cultivation and commitment: New insights on voluntary dues. UJA-Federation of New York. https://www.ujafedny.org/api/v2/assets/788990/. Accessed 18 January 2021.

Rohrbacher, Angelika. 2016. Invisible fences: The construction of "insiders" and "outsiders" in Jewish historiography. Method and Theory in the Study of Religion. 28 (4-5): 337-364.

Roof, Wade Clark. 1999. Spiritual marketplace: Baby boomers and the remaking of American religion. Princeton: Princeton University Press.

Rose, Peter I. 1994. Blaming the Jews. Society 31 (6): 35-40.

Saldaña, Johnny. 2013. The coding manual for qualitative researchers, 2nd ed. London: SAGE Publications Ltd.

Samson, Maxim G.M. 2020. Protecting religious liberties? Security concerns at places of worship in Chicago. Geoforum 117: 144-153.

Samson, Maxim G.M., Robert M. Vanderbeck, and Nichola Wood. 2018. Fixity and flux: A critique of competing approaches to researching contemporary Jewish identities. Social Compass 65 (1): 97-113.

Scheitle, Christopher P., and Caitlin Halligan. 2018. Explaining the adoption of security measures by places of worship: Perceived risk of victimization and organizational structure. Security Journal 31: 685-707.

Scheitle, Christopher P., and Jeffery T. Ulmer. 2018. Profane concerns in sacred spaces: The challenges and consequences of implementing security measures in religious congregations. Journal of Applied Security Research 13 (1): 29-44.

Schneier, Bruce. 2009. Beyond security theater. New Internationalist, 1 November. https://newint.org/ features/2009/11/01/security. Accessed 21 January 2021.

Shah, Khushbu. 2017. Where Dylann Roof killed, a search for answers. CNN, 12 January. https://www. cnn.com/2017/01/12/us/mother-emanuel-bible-study-dylann-roof/index.html. Accessed 21 September 2020 .

Shain, Michelle, Shira Fishman, Graham Wright, Shahar Hecht, and Leonard Saxe. 2013. "DIY" Judaism: How contemporary Jewish young adults express their Jewish identity. The Jewish Journal of Sociology 55 (1-2): 3-25.

Sheskin, Ira M., and Arnold Dashefsky. 2020. United States Jewish population. In American Jewish year book 2019, vol. 119, ed. Arnold Dashefsky and Ira M. Sheskin, 135-231. Cham: Springer.

Sheskin, Ira M., and Harriet Hartman. 2015. Denominational variations across American Jewish communities. Journal for the Scientific Study of Religion 54 (2): 205-221.

Soule, Sarah A., and Nella Van Dyke. 1999. Black church arson in the United States, 1989-1996. Ethnic and Racial Studies 22 (4): 724-742.

Stavans, Ilan. 2019. How the AMIA attack changed Latin American Jewry forever. Jewish Telegraphic Agency, 9 July. https:/www.jta.org/2019/07/09/opinion/how-the-amia-attack-changed-latin-ameri can-jewry-forever. Accessed 19 January 2021.

Stucker, Matthew, and Catherine E. Shoichet. 2014. 3 killed in shootings at Kansas City-area Jewish centers. CNN, 14 April. https://www.cnn.com/2014/04/13/us/kansas-jewish-center-shooting/index.html. Accessed 21 September 2020. 
Taylor, Charles. 2007. A secular age. Cambridge: The Belknap Press of Harvard University Press.

Tigges, Leann M. 2006. Community cohesion and place attachment. American Behavioral Scientist 50 (2): 139-141.

Tönnies, Ferdinand. 1988. Community and society (Gemeinschaft und Gesellschaft). New Brunswick: Transaction Inc.

Valentine, Gill. 2007. Theorizing and researching intersectionality: A challenge for feminist geography. The Professional Geographer 59 (1): 10-21.

Verkaaik, Oskar. 2014. The art of imperfection: Contemporary synagogues in Germany and the Netherlands. Journal of the Royal Anthropological Institute 20 (3): 486-504.

Vertovec, Steven. 2009. Transnationalism. London: Routledge.

Voas, David, and Mark Chaves. 2016. Is the United States a counterexample to the secularization thesis? American Journal of Sociology 121 (5): 1517-1556.

Weisskirch, Robert S., Su Yeong Kim, Seth J. Schwartz, and Susan Krauss Whitbourne. 2016. The complexity of ethnic identity among Jewish American emerging adults. Identity: An International Journal of Theory and Research 16 (3): 127-141.

Wuthnow, Robert. 1998. Loose connections: Joining together in America's fragmented communities. Cambridge: Harvard University Press.

Yuval-Davis, Nira. 2006a. Belonging and the politics of belonging. Patterns of Prejudice 40 (3): 197-214.

Yuval-Davis, Nira. 2006b. Intersectionality and feminist politics. European Journal of Women's Studies 13 (3): 193-209.

Publisher's Note Springer Nature remains neutral with regard to jurisdictional claims in published maps and institutional affiliations. 